\title{
PUblic ADMINISTRATION AND THE PROTECTION OF PRIVATE RIGHTS: QUESTIONING ITS RECOGNITION AND APPLICATION UNDER UKRAINIAN LAW
}

LA ADMINISTRACIÓN PÚBLICA Y LA PROTECCIÓN DE LOS DERECHOS PRIVADOS:

CUESTIONANDO SU RECONOCIMIENTO Y APLICACIÓN BAJO EL DERECHO UCRANIANO

\author{
Oksana Brusakova* \\ Oleksandra Karmaza** \\ Viktor Vasylenko*** \\ Vita Moroz ${ }^{* * * *}$
}

\begin{abstract}
Every society needs the recognition and protection of the rights of its citizens, and this becomes more proper for every administration in respecting this protection for the common good of its society. In this article, international experience of protecting private rights in the sphere of public administration has been analyzed. On the basis of the researched information the authors have provided concrete ways of implementing the specified international experience into domestic state and his legal system. The essence and characteristic features of legal ways to protect the legitimate interests of private individuals within public relations have been clarified
\end{abstract}

\footnotetext{
* Doctor of Law. Associate Professor. Dean of the Faculty 6 of Kharkiv National University of Internal Affairs (Kharkiv, Ukraine). https://orcid.org/0000-0001-8616-0424. advokat.brusakova@gmail.com

** Doctor of Science (Law). Professor. Professor of the Department of Civil Procedure of the Institute of Law of Taras Shevchenko National University of Kyiv (Kyiv, Ukraine). https://orcid.org/0000-0003-4895-5220. oleksandra4572@ukr.net

*** Doctor of Law. Associate Professor. Dean of the Faculty 5 of Kharkiv National University of Internal Affairs (Kharkiv, Ukraine). https://orcid.org/0000-0002-9313-861X. Vasylenko_Viktor@ukr.net

**** Doctor of Law. Department of Administrative Law, Procedure and Administrative Activity of Dnipropetrovsk State University of Internal Affairs (Dnipro, Ukraine). https://orcid.org/0000-0003-4433-3731.067546316777@ukr.net
} 
among other things. The genesis of the development of the ways to protect private rights in the sphere of public administration has been analyzed. Particular attention has been paid to the insufficient capacity of Ukraine to ensure the inviolability of private rights, freedoms and interests of the entities of public legal relations, compared to the developed countries of Western Europe and North America. At the same time, the emphasis has been made on the gradual increase in the level of democracy and the rule of law in Ukraine over the last 20 years. It has been claimed that a special "acceleration" of the indicated reforms took place immediately after two socially important events, namely the Orange Revolution of 2004 and the Revolution of Dignity of 2013-2014. However, the so-called "energy fervor" gained at the beginning of the reform is slowing down in Ukraine.

Keywords: A Private Individual, Protection of Rights, State Policy, Public Administration, Inviolability of Rights

Resumen: Toda sociedad necesita el reconocimiento y protección de los derechos de sus ciudadanos, y ello es propio de la administración, a través del respeto de esta protección por el bien común de dicha sociedad. En el presente artículo, se analiza la experiencia internacional de protección de derechos privados en el ámbito de la administración pública. Sobre la base de la información investigada, los autores han proporcionado formas concretas de implementar la experiencia internacional en el estado nacional y su sistema legal. Se han aclarado, entre otras cosas, la esencia y los rasgos característicos de las formas legales de protección de los intereses legítimos de los particulares dentro de las relaciones públicas. Se ha analizado la génesis del desarrollo de las formas de protección de los derechos privados en el ámbito de la administración pública. Asimismo, se ha prestado especial atención a la insuficiente capacidad de Ucrania para garantizar la inviolabilidad de los derechos, libertades e intereses privados de las entidades de relaciones jurídicas públicas, en comparación con los países desarrollados de Europa Occidental y América del Norte. Al mismo tiempo, se ha hecho hincapié en el aumento gradual del nivel de democracia y el estado de derecho en Ucrania durante los últimos 20 años. Se concluye que una "aceleración" especial de las reformas indicadas tuvo lugar inmediatamente después de dos eventos socialmente importantes: la Revolución Naranja (2004) y la Revolución de la Dignidad (2013-2014). Sin embargo, el llamado "fervor energético", ganado al comienzo de la reforma, se está desacelerando.

Palabras clave: Particular, protección de derechos, política estatal, administración pública, inviolabilidad de derechos 
Summary. I. Introduction. II. Research Purpose and Objectives. III. Methodology. IV. Results and Discussion. V. Conclusions. References.

\section{INTRODUCTION}

The rule of respect to legal freedoms and protection of citizenship rights is very important for different reasons and in fact, is an important achievement (Emadoleslami \& Ghorbani, 2019). The review of the real state of affairs with the observance of proper protection of private rights in the relations of public administration was always distinguished by its relevance in the scientific and legal sphere. Due to the fact that Ukraine is currently undergoing dynamic changes and reforms, much attention is paid to the issues that are in one way or another related to the protection of private rights. In a certain sense this stems from the fact that the security of private individuals and their rights, freedoms and legitimate interests are paramount for Ukraine's allies (countries of Central and Western Europe and North America). In this context, we distinguish the special (priority) position of private rights in the legal system of Western countries.

The inviolability of life, health and property of a person is recognized as the highest value, which must be protected, including in the public and legal sphere. Proper adherence to this element is the main requirement for continued cooperation of the Ukrainian state and domestic society with Western partners and allies. Adequate protection of private rights in the sphere of public administration is a mandatory clause in the plan of any reform related to the public administration area and the provision of public services.

The developed countries of Western Europe and North America have gone through a long and successful history of establishing the fundamental private rights of private individuals and protecting them from unlawful encroachments. The societies of their states passed on the knowledge and traditions of proper observance of private rights from generation to generation, while maintaining an inviolable respect for these values within these societies.

Many scholars had interest in issues related to the characteristic features of protecting private individuals within public and legal relations. However, given the rapidity and dynamism of today's realities, we believe it necessary to provide the most relevant information in this article on this issue and to form the author's vision based on the latest publications of scholars. 


\section{RESEARCH PURPOSE AND OBJECTIVES}

The purpose of this article is the scientific and legal justification of the need to protect private rights in the sphere of public and administration legal relations. The article's objective is to find and identify perspective legal ways to protect private rights of individuals and their implementation into the national legislation of Ukraine. It is really true that the essence of every society that want to succeed in ensuring effective functioning of its public service, must endeavors that every of its citizens has a wonderful life. The problem is not just talking about the necessity in providing adequate protection of rights, but by equally ensuring that these rights are respected to the fullest by every State. Even though international commitments have seen the need in ensuring private right, but of what use will such right be useful if it cannot be guaranteed by the State of Ukraine.

\section{MethodologY}

The author of the article used bibliographic method of research, which assisted to receive up-to-date information from leading foreign and domestic researchers of the present in regard to the current state of affairs in the field of legal protection of private individuals and their legitimate interests while implementing public administration by state authorities and other management entities.

In addition, the empirical and empirical-theoretical method was used, which was necessary for the proper disclosure of the terms important for the topic of this article. The use of historical and legal method was stipulated by the implementation of historical and legal analysis of the emergence and development of legal ways to protect the rights and interests of private individuals during public and administration activities.

Instead, comparative method was used to classify different systems of protection of private rights within public and legal conflicts in different countries of the world according to their effectiveness in the domestic sphere. As a result, the author of the article has identified the most suitable ways to adopt. Wonderfully with all its beautiful placement as to the methodology used in proving that the public administration is taken care of private rights in Ukraine as stipulated under international prescription. The problem is not just stating that the State of Ukraine sees the need recognizing these rights, our problem is out to examine whether this right is effectively implemented in Ukraine. It will be of unfruitful explanation if right is stated 
and provided, and implantation is futile. What has the State of Ukraine done so far in ensuring that this right is highly protected without any level of discrimination? The problem is really a difficult nut to crack as we continue experiencing the improper application of this right giving ground for questioning as to the need in having the right.

\section{RESULTS AND DISCUSSION}

The problems of securing peace and protecting human rights can only be achieved by peaceful means, based on the international rule of law (Demenchonok, 2009). Human rights theory aims at giving the best philosophical account of human rights. The general aims of human rights theory are, in particular, understanding the nature and function of human rights; determining the object, normative content, right-holders and dutybearers of human rights; providing a justification of human rights and accounting for the legitimacy of international human rights law; and, more generally, providing critical, normative guidance to human rights practice. What human rights theory should do therefore is account for the current human rights practice, but also criticize it at the same time. It follows that human rights theory implies focusing on the contemporary human rights practice as an object of philosophical enquiry (Besson, 2013, pp. 125-126). Human rights are a complex phenomenon incorporating many different aspects. They have a moral life, of expressing human problems and claims that should not be violated or ignored anywhere on the globe; they also have a legal life fixed in national constitutions and in international declarations, covenants and treaties; they have political life as the basic standards of political legitimacy. Therefore, they are a centuries-old topic in the political sphere, in national and transnational level and will never lose its relevance in science and in other spheres of life of mankind (Nemerebaeva, 2019). Human rights can be understood as moral propositions, and more specifically as moral propositions that ground moral duties. They are part of morality, just as reasons, values, duties, principles or interests. They ought not, however, be identified with all the latter nor taken to exhaust morality. In particular, human rights are of value and can be justified on the basis of values, but are not themselves values (Besson, 2009).

At the heart of international human rights law lies a practical challenge intertwined with a theoretical problem. The practical challenge is that many of the most grave and systematic human rights abuses occur during public emergencies, when states employ extraordinary powers to address threats to public order. The "cornerstone[s]" of these covenants are their derogation 
clauses, which permit states to restrict some human rights during emergencies - but only where strictly necessary to address threats to "the life of the nation" or the "independence or security" of the state. This derogation-centric approach enables IHRL to accommodate concerns for public necessity during emergencies, but it also poses a vexing theoretical problem. In what sense are human rights rights if they are subject to derogation during emergencies? (Criddle \& Fox-Decent, 2012, p. 40).

The administrative-legal mechanism of protection of subjective public rights of an individual is a component of the administrative-legal mechanism of ensuring the rights and freedoms of an individual. The administrativelegal mechanism of protection of subjective public rights of an individual is a theoretical construction, which contains in its structure the normative basis, system subject composition and formal procedure of administrativelegal measures in the field of preventive protection and protection and restoration of violated public interests. The institutional component of the administrative and legal mechanism for the protection of subjective public rights is the system of public authorities and local self-government. Problems of ensuring the effectiveness of the implementation of the administrative-legal mechanism of subjective public rights are the lack of legal regulation of administrative procedures, law enforcement gaps in the regulation of the exercise of discretion by the authorities, etc. (Chub, 2020).

Based on the examples of foreign countries, we can observe the extremely important role played by the proper protection of private rights in public and administrative relations. There are long traditions of protection and inviolability of private rights in European countries. In particular, it is argued that the rights of private individuals in the field of administrative (managerial) activities are protected not only by generally accepted "traditions". Private individuals in the developed countries of the West are endowed with concrete and effective tools to protect their violated private rights in practice. Among other things they have an undisputed right to demand the restoration of their violated rights from the entity of legal relations (in this case public one) that actually violated them. It is one of the most famous tools for protecting the rights in administrative law. The very essence of the requirement for the violator to stop the violation, or compensate for it, is rooted in civil law, and if we conduct a more in-depth analysis, we can study the origin of this legal phenomenon since the times of Roman private law.

It will be pertinent to note that it is necessary to establish fair (where necessary, equal) "rules of the game" within legal relations, in addition to providing individuals with specific, practical and legal instruments to protect their private rights. In other words, the legal regulation of public 
administration area should ensure a "fair initial condition" for the functioning of each entity of legal relations. Some legal scholars prefer to call this equality of parties within legal relations.

In a particular sense, we are inclined to agree with this, since we believe that ensuring the inclusive participation of each of the entity in these legal relations is a prerequisite for their effective functioning. Moreover, in our opinion, it is one of the main criteria of public legal relations in a democratic state with real rule of law. Many lawyers point out that the issues covered in this article are related to historical factors. For example, it is applied to past political regimes that operated in Ukraine before the proclamation of independence in 1991.

Considering the example of the totalitarian Soviet regime, it is not difficult for an experienced researcher to notice a characteristic feature of its legal system, which had an impact on the daily life of the entire society. Namely, it is a question of full subordination of all entities of public legal relations to the state and its agencies. This state of affairs is classic for authoritarian and especially totalitarian regimes. Private rights of individuals under such circumstances are always under constant threat of their violation in favor of the interests of the state and its leadership.

Hence, it follows that a private individual does not have the opportunity to protect the violated rights or affected interests in court and in any other legal proceedings "on an equal footing", unlike government agencies and institutions. Therefore, scholars emphasize the strong link between the democracy of the political regime, the rule of law in a particular state and the quality of its governance sector. It is stated that domestic administrative and legal science in order to fulfill the task of creating appropriate mechanisms to protect the rights and legitimate interests of private individuals, should focus on the compliance with the humancentered model of functioning.

It is believed that the standard of the human-centered model of the legal system is the one, where all entities of both public and private legal relations (including the state and its agencies) will contribute to the inviolability of the rights and legitimate interests of each other. In such circumstances, the rights and interests of private individuals are highly valued and properly respected within legal relations between individuals.

Scholars note that there are currently some difficulties in Ukraine with the full functioning of the human-centered model in the system of public administration. It is partly due to the fact that our country has traditionally been dominated by the opposite system of governance of society and the state.

Since the days of the Russian Empire, there was a thought that the private interests and even the fundamental rights of citizens or the private 
interests of trade associations were null compared to the interests and priorities of the state and its leadership. Due to the long existence of serfdom, as well as many other practices of legal inequality of entities of legal relations, the rights and interests of private individuals were significantly damaged, as well as their ability to effectively protect their rights was damaged (almost completely destroyed). Unfortunately, those negative traditions continued for society for most of the XX century during the Soviet era. Collectivization and the ban on owning private property for more than 70 years greatly complicate modern processes of restoring respect for the private rights of individuals.

Another problem in this area was the exact opposite of today's orientation of administrative and legal science. For example, it has been emphasized that the dominant view of administrative law throughout the Soviet era was the understanding of the state as the central and most important entity in the field of public administration, as well as in the entire system of law of that time. Therefore, its interests were recognized as paramount, and the rights and interests of other entities of legal relations, including private individuals, were allowed to be violated and terminated in favor of the state.

The country finally began to take some steps to protect the rights and interests of private individuals during the processes related to public administration only with Ukraine's independence in 1991. Accordingly, domestic administrative and legal science, got away restrictions on the promotion of scientific opinions and views independent of the "official" position of the state, has become able to provide society with quality theoretical justification for the need to protect private interests within public and administrative legal relations. In particular, it is worth focusing on the publications of O. M. Paseniuk (2008) and T. O. Matselyk (2011), who outlined the importance of respecting the inviolability of the rights and legitimate interests of private individuals during public and legal (public and administrative) processes. Over time, this view of the role of private rights in public administration has been supported, even improved by other scholars in the legal field. We can even conclude that the assertion that the rights and legitimate interests of the individual are no less important than the interests of the state, has become the most common scientific opinion among researchers of administrative law since the first years of Ukraine's independent.

It should be noted that the developed countries of the West have played the leading role in increasing the attractiveness of protection of the rights, freedoms and interests of private individuals among Ukrainian society. In particular, they encouraged both the leadership of Ukraine and its ordinary citizens to establish high standards of democracy and the rule of law in their 
country by their own bright example. In addition, the European countries, as well as Canada and the United States, laid the foundations for fruitful cooperation between Ukraine and these countries. They also influenced the cultivation of respect for private rights in public legal relations (Sever, et al., 2015; Koprić, 2019).

We can clearly see how effective the respect to private rights of individuals in all legal relations for the country by the example of Western European countries is, as well as the above-mentioned United States and Canada. It is also related to the adherence to human-centered model of public administration. It should be noted that, for example, the tradition of the United States of proper protection of the rights and interests of private individuals in public relations is as old as the history of this country since its independence of 1776 (Bergling, et al., 2008).

The protection of private rights of individuals in the United States has undergone particularly clear definitions in 1928 during the Olmsted v. United States trial. The importance of the inviolability of private rights during public and administration activities was for the first time confirmed in world legal practice during the hearing of this case.

The state represented by its agencies in the vast majority of Western countries, is obliged to guarantee the protection of private rights and to ensure proper observance of high standards of such protection. It has been argued that the state's responsibilities to protect the above goods stem to some extent from its international obligations. The latter may be contained in international treaties, conventions and other legal documents signed by government or delegated persons. The influence of the international community on the state's observance of the rights, freedoms and legitimate interests of each private individual, without exception, is quite effective, especially if it is supported by other ways (Vovk, 2019).

The national legal system and the judiciary of Ukraine have been increasingly influenced by European norms and principles of law since the independence, but especially since 2014. After joining the Council of Europe in 1995, the country almost immediately began to feel the influence of the European legal system. Therefore, noting the current state of affairs in the field of protecting private rights in the field of public administration, we emphasize that Ukraine has mastered the ways to effectively implement the positive experience of developed foreign countries in the studied field over the years of independence (Hamalii, 2014; Honcharuk, 2017; Kuleshov, 2018). In particular, Ukrainian society has finally understood the importance of guaranteeing the rights of private individuals in public managerial and administration processes. It is necessary to mention among other things, the removal of information barriers and the removal of 
restrictions on travelling abroad, which existed before 1991. Those measures influenced the fact that citizens began to travel the world and gained access to various sources of information. And that, in turn, had a decisive impact on their understanding and awareness of the important need to protect the rights of private individuals within public legal relations. It is also worth noting the positive tendency of the Internet, which allowed private individuals to freely familiarize themselves with foreign law, case law and other important elements of the administrative and legal mechanism for protecting private rights in the sphere of public administration (Khadzhyradieva, et al., 2020).

Administrative and legal mechanism for protecting the rights, freedoms and interests of individuals and legal entities is a complex, systematic and comprehensive category of administrative law endowed with regulatory, defense and protective functions in relations between nongovernmental entities and state authorities, local self-government agencies, their officials and civil servants. Definition of the administrative and legal mechanism for protecting the rights, freedoms and interests of individuals and legal entities indicates the undeniable importance of the administrative process as part of administrative law of Ukraine, because it is impossible to provide and form an efficient and effective mechanism for protecting private rights in administrative and legal relations without the existence of procedural means of implementing administrative substantive norms in the country. An integrated approach to the formation of theoretical and practical foundations of the administrative and legal mechanism for protecting the rights, freedoms and interests of individuals and legal entities provides an opportunity to fully and comprehensively take into account constitutional requirements on guaranteeing the rights, freedoms and interests of individuals and legal entities by the subjects of authoritative power both at the legislative and rulemaking levels (Muza, 2018).

The legal awareness of citizens has significantly increased, and they have learned to demand and receive the proper quality of processes and mechanisms to protect their rights. It has become clear within society that the rights of all private individuals, without exception, must be properly guaranteed and protected from unlawful encroachments. Since it is the main condition for the effective functioning of the entire national legal system. 


\section{CONCLUSIONS}

Thus, the protection of private rights in the sphere of public administration is and will certainly be one of the key problems of domestic administrative law science, as well as society and the state in the whole.

1. It has been substantiated that the most effective tools for protecting of the rights of private individuals in public and administrative relations are the undisputed right to demand the restoration of their violated rights from the entity of legal relations (in this case public one), which actually violated them, as well as the possibility of specific actions for self-defense or involvement of a lawyer into such protection.

2. The situation with respect for private rights in the course of public administration has become significantly more effective since Ukraine's independence in 1991. Undoubtedly, Ukraine's closer accession to legal (including judicial) cooperation with developed European countries has made a great contribution to improving the effectiveness of legal mechanisms that protect the inviolability of the rights and legitimate interests of private individuals. The political factor, which is the positive pressure of Western democracies on the top leadership and the political class of the state, deserves good praise, since it has repeatedly provided critical support for the efforts to improve mechanisms of protecting private rights.

3. The combination of the above factors will be able to decisively improve the domestic situation concerning the protection of private rights in the public administration area. It has been emphasized that, although Ukraine has already made significant progress in protecting the rights of private individuals, there are still open directions and horizons for further achievements in this area, especially through the use of the experience of developed foreign countries. 


\section{REFERENCES}

Bergling, P., Bejstam, L., Ederlöv, J., Wennerström, E., \& Sannerholm, R. Z. (2008). Rule of Law in Public Administration: Problems and Ways Ahead in Peace Building and Development. Folke Bernadotte Academy.

Besson, S. (16-V-2009). The Human Right to Democracy: A Moral Defense with a Legal Nuance. Unidem Seminar "Definition and Development of Human Rights and Popular Sovereignty in Europe”. Frankfurt, Main, Germany.

Besson, S. (2013). The Law in Human Rights Theory. Zeitschrift für Menschenrechte, Journal for Human Rights, 13 (1), 120-150.

Chub, A. V. (2020). Structure of the Administrative and Legal Mechanism of Protection of the Subjective Public Rights of a Private Person. Law Bulletin, 14, 163-170. Doi: https://doi.org/10.32850/LB2414-4207.2020.14.20

Criddle, E. J., \& Fox-Decent, E. (2012). Human Rights, Emergencies, and the Rule of Law. Human Rights Quarterly, 34, 39-87.

Demenchonok, E. (2009). The Universal Concept of Human Rights as a Regulative Principle: Freedom versus Paternalism. The American Journal of Economics and Sociology, 68 (1), 273-302.

Emadoleslami, Z., \& Ghorbani, H. (2019). Preliminary Phase of the Right of Assessment in Iran and France with Emphasis on One Article to Respect Legal Freedom and Protection of Citizenship Rights. Jurnal Cita Hukum, 7 (3), 335-350. Doi: 10.15408/jch.v7i3.11542

Hamalii, O. L. (2014). Rights of Citizens as an Object of Private and Legal Protection by State Authorities. Law and Safety, 1, 28-33.

Honcharuk, S. T. (2017). Realization of the Right to Protection Within Proceedings on Administrative Offenses. Internauka, 4 (2), 100-104.

Jasanoff, S. (2012). Taking Life: Private Rights in Public Nature. In Kaushik Sunder Rajan (Ed.), Lively Capital: Biotechnologies, Ethics, and Governance in Global Markets. Duke University Press.

Khadzhyradieva, S., Slukhai, S., \& Rachynskyi, A. (2020). Public Administration in Ukraine: Adjusting to European Standards. NISP Acee Journal of Public Administration and Policy, 13, 81-108.

Koprić, I. (6-X-2019). Public Administration in a Democratic Society: Thirty Years of Democratic Transition in Europe. Centre for Advanced Academic Studies (CAAS). Dubrovnik, Croatia.

Kuleshov, D. V. (2018). Court Protection of Human Rights as a Guarantee of Constitutional System of Ukraine. The Journal of V. N. Karazin Kharkiv National University, 25, 148-151.

Matselyk, T. O. (2011). Subjective Public Law as a Legal Phenomenon. Law Herald, 3 (20), 67-71. 
Muza, O. V. (2019). The Administrative Legal Mechanism to Defense the Rights, Freedoms and Interests of the Physical and Juridical Persons in Ukraine.

Nemerebaeva, A. (2019). The Justification of Human Rights in Public Administration. [Correspondence]. The European Journal of Law and Political Sciences, 1 (2), 22-24. Doi: https://doi.org/10.29013/EJLPS-19-1.2-22-24

Noeske, J. (2014). Private Rights vs. Public Good: A Matter for Opinion Polls? The International Journal of Tuberculosis and Lung Disease, 18 (9), 1132-1132. Doi: https://doi.org/10.5588/ijtld.14.0149

Paseniuk, O. M., \& Kornuta, R. I. (2008). On the Nature of Subjective Public Law. Law of Ukraine, 8, 58-63.

Russell, A. (2003). Private Rights and Public Policy. Computer Law \& Security Review, 19, 411-415.

Sever, T., Rakar, I. \& Kovač, P. (2015). Protecting Human Rights Through Fundamental Principles of Administrative Procedures in Eastern Europe. DANUBE, 5 (4), 249-275. Doi: https://doi.org/10.2478/danb-2014-0014

Sigmundová, E. (2017). Means of Protection of Individual Rights in Public Administration: System and Efficiency. Public Governance, Administration and Finances Law Review, 2 (1), 56-58.

Vovk, P. V. (2019). Protection of the Rights, Freedoms and Legitimate Interests of Private Individuals as the Mission of Administrative Legal Proceedings Existence. Comparative-Analytical Law. Doi: 10.32782/2524-0390/2019.6.133 